\title{
Anticholinergic Agent
}

National Cancer Institute

\section{Source}

National Cancer Institute. Anticholinergic Agent. NCI Thesaurus. Code C66880.

Any agent that binds to and blocks nicotinic and/or muscarinic receptors, thereby

preventing the actions of the neurotransmitter acetylcholine (Ach) at these receptors. 